\title{
Antibiofilm activity of flavonoid mangosteen pericarp extract against Porphyromonas gingivalis bacteria
}

\author{
Aprillia Sonya Federika, Mandojo Rukmo and Setyabudi \\ Department of Conservative Dentistry \\ Faculty of Dental Medicine, Universitas Airlangga, \\ Surabaya, Indonesia
}

\begin{abstract}
Background: Necrosis teeth need a procedure called the root canal treatment to eliminate microorganisms in root canal, so the inflammation process did not continue to the periapical. One of the microbes that exist in the necrosis teeth is Porphyromonas gingivalis, that capable of forming biofilm because it has the ability to communicate with bacteria signaling (quorum sensing). It is necessary to discover another antibiofilm agent as an irrigation material in root canal preparation deriving from nature. Flavonoid mangosteen pericarp extract can disrupt acyl-homoserine lactones (AHLs) thus quorum sensing bacteria will be disrupted and causing permanent attachment and the establishment of colonies on the surface of the teeth any barrier. Purpose: The aim of this study found out the antibiofilm activity of flavonoid mangosteen pericarp extract against Porphyromonas gingivalis bacteria. Methods: This study has a laboratory experimental with post-test only group design. Porphyromonas gingivalis ATCC 33277 was diluted according to Mc. Farland standard $10^{6} \mathrm{CFU} / \mathrm{ml}$ in Tryptic Soy Broth (TSB) medium and inserted into microtitterplate flexible U bottom. Porphyromonas gingivalis was incubated for $6 \times 24$ hour and checked with a simple staining to see the formation of biofilm. Flavonoid mangosteen pericarp extract was added in various concentrations and OD (optical density) readings done with a wavelength of $595 \mathrm{~nm}$. Results: Flavonoid mangosteen pericarp extract showed a decrease of OD value from control in all concentrations. Conclusion: Flavonoid mangosteen pericarp extract has antibiofilm activity against Porphyromonas gingivalis bacteria.
\end{abstract}

Keywords: Flavonoid mangosteen pericarp extract; biofilm; Porphyromonas gingivalis

Correspondence: Aprillia Sonya Federika, Department of Conservative Dentistry, Faculty of Dental Medicine Universitas Airlangga. Jl. Mayjen Prof. Dr. Moestopo No. 47 Surabaya 60132, Indonesia. E-mail: aprilia_sonya@ymail.com.

\section{INTRODUCTION}

Dental caries is an infectious disease which mainly affects hard tooth tissue, causing local hard tissue damage. Bacteria in caries tissue will produce toxins that will penetrate into the pulp and root canal through the dentinal tubules. If there is no treatment, the pulp inflammation will get worse and there is a change in blood circulation in the pulp, causing tooth necrosis. One of the microbes in tooth necrosis is Porphyromonas gingivalis of $4.6 \% \%^{2}$.

Porphyromonas gingivalis is an anaerobic non-motile gram-negative black pigmented bacterium that can be found in the oral cavity. One of the virulence factors of Porphyromonas gingivalis is LPS (endotoxin) which is associated with tissue destruction and the incorporation of extracellular matrix in the pulp and periapical disease, as well as mediators of pain causes due to bradykinin stimulated by Porphyromonas gingivalis ${ }^{3,4}$. This can lead to failure in root canal treatment because these bacteria can form biofilms as microorganism defenses against antibiotics and immune responses 5 .

Biofilm is a microbial aggregate of similar and different types attached to the surface of biological and non-biological substrates where one cell with other cells are bound to and attached to the substrate by means of an extracellular polymeric substance (EPS) matrix ${ }^{6}$. Bacteria in biofilms make it possible to survive in a low nutrient environment in the root canal $^{7}$ thus a chemical procedure is needed to eliminate the biofilm of the bacteria Porphyromonas gingivalis by irrigation in root canal treatment.

Mangosteen (Garcinia mangostana L.) is a tropical fruit that has been widely used as traditional medicine in Southeast Asia, especially the skin of the fruit. Mangosteen rind shows the presence of saponins, tannins, xanthones, and flavonoids. Some active components of the mangosteen rind that can be used as an antibiofilm, one of them is flavonoids.

Flavonoids are a group of phenol compounds that work by disrupting acyl-homoserine lactones (AHLs), hence 
quorum sensing bacteria or bacterial signaling will be disrupted. AHLs are signaling molecules in bacteria that play a role in biofilm formation ${ }^{8}$. Besides that, the ability of flavonoid compounds in the phenol group to make bacterial enzymes become inactive, causing the activity of the glycosyltransferase enzymes used by bacteria to synthesize sucrose in the media into glucans. As a result, the formation of biofilms is inhibited because the amount of glucans as a medium for attachment of bacteria is small or limited ${ }^{9}$. This study aims to determine the power of the mangosteen skin flavonoid antibiofilms against Porphyromonas gingivalis bacteria.

\section{MATERIALS AND METHODS}

This study was an in vitro laboratory experimental research with a study design that is used post-test only control group design. The study was conducted at the Tropical Infection Disease Hospital (RSPTI), Research Institute and Industrial Consultation (BPKI) Laboratory, Surabaya, East Java from June to October 2014.

Samples from this study were single species Porphyromonas gingivalis strain ATCC 33277 obtained from RSPTI Universitas Airlangga and cultured to form biofilms on TSB (Tripoyase Soy Broth) media for 6 days. The independent variable in this study was mangosteen skin flavonoids, while the dependent variable was the power of the Porphyromonas gingivalis antibiofilm.

Mangosteen peel was obtained from the town of Medica materia town of Batu and extracted were taken and the active compound was taken from the flavonoid at the Laboratory for Research and Industrial Consultation (BPKI) Laboratory, Surabaya. Mangosteen peel that has been dried, crushed thus it will get 20-40 mesh granules and put into the extractor tool. Added $96 \%$ ethanol solvent with mangosteen: ethanol skin ratio was 1: 2 . Stirring with stirrer / shaker for $2 \times 24$ hours, then filtered to obtain clear red filtrate. Evaporated at $60^{\circ}$ by using a vacuum evaporator until all the ethanol was separated to obtain thick brown mangosteen peel extract krude approximately $5 \%$ of the weight of the mangosteen peel. Krude mangosteen peel extract was taken 10 gr then put into the separator / funnel separator. It was added with acetone benzene with a ratio of 1: 1 of $100 \mathrm{ml}$. Shook for 2 hours to the shaker. Let stand so that the top liquid was clear. The faucet under the separator was opened slowly, thus $1 / 2$ solid dirt comes out. The clear liquid was transferred to a vacuum evaporator, hence all the solvents were separated. Flavonoid extract obtained in the form of a thick $1 / 2$ solid viscous dark red.

The antibiofilm power test was performed by adding $0.1 \mathrm{ml}$ of suspension from the test material on day 6 with a concentration of $100 \%, 50 \%, 25 \%, 12.5 \%, 6.25 \%, 3.125 \%$, $1.56 \%$, and $0.78 \%$ into each microplate well with 3 wells was not given a suspension of test material as a control. P. gingivalis biofilms that have been added to the test material are incubated for 24 hours at $37^{\circ} \mathrm{C}$. After that, the contents of each well are aspirated and washed 4 times using phosphate buffer saline. Then did the painting with crystal violet and incubated at room temperature for 15 minutes and rinsed with distilled water 3 times then dried. Added 100\% DMSO color solvent as much as $0.1 \mathrm{ml}$. Then the microtitter plate was shaken for 1 minute and placed in a microplate reader. To quantitatively analyze the antibiofilm power of each test material, optical density measurements were taken at a wavelength of $595 \mathrm{~nm}$ using a microplate reader. Each isolate was repeated 3 times. The data obtained were analyzed parametrically with the one-way ANOVA test.

\section{RESULTS}

The results of this study were obtained from the $\mathrm{P}$ gingivalis biofilm strain ATCC 33277 which was formed on TSB media and given test material namely mangosteen skin flavonoids with the concentrations used were $100 \%, 50 \%$, $25 \%, 12.5 \%, 6.25 \%, 3.125 \%, 1.56 \%$, and $0.78 \%$ with positive and negative controls. The power of antibiofilms in each test material that can degrade Porphyromonas gingivalis biofilms can be determined by reading OD (Optical Density) using a microplate reader. Each study group consisted of 3 samples. The results obtained were converted to biofilm viability percentage, i.e. ${ }^{10}$ :

$$
\text { Viability }=\frac{\text { OD Value of treatment group }}{\text { OD Value of control group }} \times 100 \%
$$

According to OD (Optical Density) values which see the turbidity level of bacterial suspensions using a microplate reader, it was found that eight concentrations showed OD values lower than OD values of the control. At concentrations of $0.78 \%$ to $25 \%$, OD values decreased, but at concentrations of $50 \%$ and $100 \%$, OD values increased.

Table 1. Measurement Result of microplate reader OD biofilm bacteria Porphyromonas gingivalis

\begin{tabular}{lcccccccccc}
\hline & \multicolumn{1}{c}{ Extract Concentration } \\
\cline { 2 - 10 } & $100 \%$ & $50 \%$ & $25 \%$ & $12.5 \%$ & $6.25 \%$ & $3.125 \%$ & $1.56 \%$ & $0.78 \%$ & $\begin{array}{c}\text { Positive } \\
\text { control }\end{array}$ \\
\hline \multirow{3}{*}{ OD biofilm value } & 0.028 & 0.022 & 0.025 & 0.038 & 0.047 & 0.067 & 0.079 & 0.137 & 0.156 \\
& 0.039 & 0.033 & 0.023 & 0.028 & 0.036 & 0.044 & 0.067 & 0.138 & 0.142 \\
\hline \multirow{2}{*}{ Mean } & 0.062 & 0.030 & 0.024 & 0.023 & 0.028 & 0.036 & 0.059 & 0.142 & 0.133 \\
\hline OD Percentage & 0.043 & 0.028 & 0.024 & 0.030 & 0.037 & 0.049 & 0.068 & 0.139 & 0.144 \\
\hline
\end{tabular}




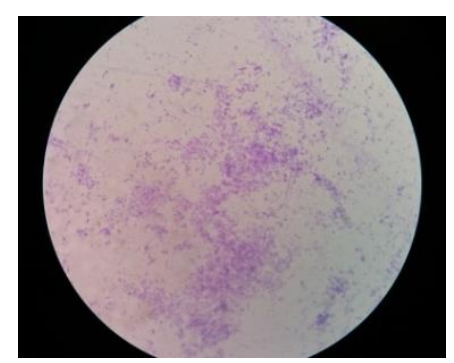

Figure 1. Porphyromonas gingivalis bacterial biofilm that grew after the $6^{\text {th }}$ day incubation was seen by using a microscope and Crystal violet staining.

Of the eight concentrations above, the concentration of $25 \%$ had the lowest OD value compared to the OD value at other concentrations of $16.67 \%$ which means that at that concentration mangosteen skin extract flavonoids were able to damage the bacterial biofilm of Porphyromonas gingivalis as much as $83.33 \%$ of the total successful bacteria that grow on positive control.

The results of this study were analyzed by using statistical analysis of SPSS version 17. Data from measurements of OD biofilms using a microplate reader were grouped and analyzed by using the SPSS program. Data normality test was conducted by the Kolmogorov-Smirnov statistical test to find out the distribution of normal data and the same variance. Based on the results of the normality test, obtained p> 0.05 which means the data were normally distributed. Furthermore, the variance homogeneity test was performed by the Levene's Test statistical test to find out whether the data distribution was eligible for the parametric test or not. From the homogeneity test results found that the data was parametric data, so the data can be tested by using One Way Annova, this was indicated by the value of $\mathrm{p}=0.082$ $(\mathrm{p}>0.05)$.

OD biofilm data were tested by using One Way Annova and continued by Post-hoc Multiple Comparation Test (Tukey Test) with a significance level of 5\%. One Way Annova test was used to find out the differences between the data groups, then continued with the Tukey Test to see the significance of the difference in the biofilm OD between the study groups. One Way Annova test results showed significance results $p=0,000(p<0.05)$ which means there were significant differences in the mangosteen peel extract flavonoids with different concentrations on the growth of Porphyromonas gingivalis biofilms.

\section{DISCUSSION}

Dental caries is one of the gateways through which bacteria enter the pulp. If dental caries is not treated immediately, then inflammation of the pulp will get worse and there is a change in blood circulation in the pulp, causing tooth necrosis. Tooth necrosis requires a root canal treatment procedure to eliminate microorganisms in the root canal thus the inflammation process does not continue into the periapical region ${ }^{1}$.
One of the microbes in tooth necrosis is Porphyromonas gingivalis where the bacteria are able to form biofilms because they have the ability to communicate with specific signals (quorum sensing). The results showed that almost $35 \%$ of the root canal surface still had a biofilm layer that was not successfully taken by the root canal file. Besides that, obturator material also has limited antibacterial activity because most sealers lose antibacterial power within one week. When the biofilm has reached the final stage, such as maturation, the normal cavity cleaning agent cannot clean the existing bacterial biofilm. This is caused by the nature of bacteria that have been resistant to antibiotics due to the formation of an extra-cellular polyshacaride matrix (EPM) layer that protects the bacteria in the biofilm. These factors cause persistent biofilms in the root canal system ${ }^{7}$. Therefore, we need irrigation materials to overcome this problem that have the power to damage the bacterial biofilm of Porphyromonas gingivalis.

This study used a flavonoid extract of mangosteen peel (Garcinia mangostana) which was applied to the bacterial biofilm of Porphyromonas gingivalis. Study with this experimental laboratory type was conducted in vitro which aims to determine the power of the mangosteen skin extract flavonoid antibiofilm at certain concentrations of the Porphyromonas gingivalis bacterial biofilm. The concentration used is the serial dilution method, because the same study has never been analysed before. The concentration of mangosteen peel extract flavonoids used were $100 \%, 50 \%, 25 \%, 12.5 \%, 6.25 \%, 3.125 \%, 1.56 \%$, and $0.78 \%$. Based on the results of the study, the concentration group of $0.78 \%$ to $25 \%$ concentration showed the average value getting smaller, this is because the higher the concentration of the material given, the more biofilms were damaged. However, the average value was getting bigger in the concentration group of $50 \%$ and $100 \%$, this was due to the high concentration of flavonoid mangosteen peel extract, resulting in a disturbance in the reading of OD. Microplate reader reading is a spectrophotometric reading so that with the thickness of the dark red mangosteen peel extract flavonoids, it causes the material to stick strongly enough to the walls of the micotiter plate, hence it can affect the reading results by the microplate reader. Another possible factor influencing the inconsistent percentage value is the improper extraction process and method, which is that the mangosteen peel should be evaporated at $40^{\circ}$ but in this study using $60^{\circ}$ thus this study found flavonoids mixed with other impurities even though the number of impurities in a small percentage. Besides that, the process of conducting study that is less thorough in terms of time, procedures, appropriateness of the use of tools and materials during the study can affect the percentage value of $50 \%$ and $100 \%$ increase.

Each concentration was repeated 3 times in this study, the results obtained showed that all concentrations could damage the biofilms produced by Porphyromonas gingivalis bacteria, because OD of bacterial biofilms treated in the form of mangosteen peel extract flavonoids were lower than OD of bacterial biofilms that were treated mangosteen peel 
extract was not given flavonoids (positive control). This is consistent with the theory that a material that has antibiofilm power can damage biofilms in a variety of ways, including by penetrating extracellular matrices, dispersing cells from biofilms, or removing EPS stability on biofilms ${ }^{11}$. Release of cells occurs due to increased fluid pressure or degradation of endogenous enzymes, as well as the release of EPS or attachment proteins ${ }^{12}$. This is also supported by the statistical test results with a value of $p=0,000(p<0.05)$ which means there are significant differences between the groups tested (mangosteen skin flavonoids against Porphyromonas gingivalis bacterial biofilms) which indicate differences in antibiofilm power between concentration groups. Thus, it can be seen that mangosteen skin flavonoids have the power of the Porphyromonas gingivalis antibiofilm.

Flavonoids, a group of phenol compounds that have effective properties that can inhibit the growth of viruses, bacteria, and fungi. The ability of phenol compounds can interfere with the signaling molecules in bacteria (quorum sensing) that function as communication media between bacteria and play a role in the process of biofilm formation. Inhibition of quorum sensing is caused due to inhibition of enzyme synthesis which is responsible for producing signaling molecules or receptor proteins that modulate quorum sensing ${ }^{8,12}$. In addition to disrupting signaling molecules in bacteria, flavonoids can also make bacterial enzymes inactive, causing the activity of the glycosyltransferase enzyme to be disrupted, as a result the glycosyltransferase enzyme cannot produce glucans which function as media for attachment of bacteria ${ }^{13}$. Besides flavonoids also have a tendency to inhibit the synthesis of nucleic acids, change the permeability of cell membranes and disrupt the metabolism that causes bacteria to eventually burst (lysis).

From the results of this study, it is hoped that there will be further research using other methods besides calculating OD values which have several weaknesses, one of which is the absorbance of the mangosteen peel extract flavonoids as well as research on the MIC and KBM values as the development of natural irrigation alternative materials in the practice of dentistry especially root canal treatment.

\section{CONCLUSION}

Based on the results of this study, it can be concluded that mangosteen skin flavonoids have antibiofilm power against the bacteria Porphyromonas gingivalis.

\section{REFERENCES}

1. Walton RE, Torabinejad M. Prinsip \& Praktik Ilmu Endodonsia. Jakarta: Penerbit Buku Kedokteran EGC; 2008. p. 30.

2. Abou-Rass M, Bogen G. Microorganisms in closed periapical lesions (Abs). International Endodontic Journal 31(1). 2008. pp. 39-47.

3. Gomes BPFA, Pinheiro ET, Gade-Neto, CR, Sousa ELR, Ferraz CCR, Zaia, AA, Teixeria, FB, Souza-Filho, FJ. Microbial Examination of Infected Dental Root Canal. Oral Microbiology and Immunology; 19. 2004. pp. 71-76.

4. Narayanan LL, Vaishnavi C. Endodontic microbiology. J conserv Dent. 13(4). 2010. pp. 233-9.

5. Noguchi N, Noiri Y, Narimatsu M, Ebisu S. Identification and Localization of Extraradicular Biofilm-Forming Bacteria Associated with Refractory Endodontic Pathogens. Applied and Enviromental Microbiology 2005; 71(12). pp. 8738-43.

6. Hall-Stoodley, L, J.W. Costerton, P. Stoodley. Bacterial biofilms: from the natural world to infectious disease. Nat. Rev. Microbiol. 2 (2).2004. pp 95-108.

7. Shrestha A. Nanoparticulates for Antibiofilm Treatment and Effect of Aging on Its Antibacterial Activity. J Endod. Vol 36. 2010. pp.1030-1035.

8. Manner S, Malena Skogman, Darla Goeres, Pia Vuorela, and Adyary Fallarero. Systematic Exploration of Natural and Synthetic Flavonoids for the Inhibition of Staphylococcus aureus Biofilms. International Journal of Molecular Sciences. 2013. pp. 19434-51.

9. Ardani, Marisya, Pratiwi, Slyvia, Hertina, Triana. Efek campuran minyak atsiri daun cengkeh dan kulit batang kayu manis sebagai antiplak gigi. Majalah Farmasi Indonesia 21(3). 2010. pp: 191-201.

10. Radianto, R. Konsentrasi Hambat Minimal Ekstrak Daun Sirsak terhadap Biofilm Bkateri Enterococcus faecalis. 2013. p. 46.

11. Donlan, Rodney M. Biofilm elimination on intravascular catheters: important considerations for the infectious disease practitioner. Oxford University Press. 2011. pp. 1038-45

12. Bueno J. Anti-Biofilm Drug Susceptibility Testing Methods: Looking for New Strategies against Resistance Mechanism. 2014. J Microbial BiochemTechnol S3: 004. doi:10.4172/1948-5948.S3-004

13. Theilacker C, Sava I, Sanchez Carballo P, Bao Y, Kropec A, Grohmann E, Holst O, and Huebner J. Deletion of the glycosyltransferase bgsB of Enterococcus faecalis leads to a complete loss of glycolipids from the cell membrane and to impaired biofilm formation. BMC Microbiology. 2011. pp. 11-67. 